\title{
Evaluation of Comfortable Improvement of the Tractor Seatbelt
}

\author{
Kwan Woo Kim ${ }^{1}$, Hyuk Joo Kim², Keun Sang Park ${ }^{3}$ \\ ${ }^{1}$ Analysis \& Certification Division, Foundation of Agri. Tech. Commercialization and Transfer, Suwon, 135-222 \\ ${ }^{2}$ National Institute of Agricultural Engineering, Suwon-city, Gyeonggi-do, 441-100 \\ ${ }^{3}$ Department of Industrial Engineering, Konkuk University, Seoul, 143-701
}

\begin{abstract}
The objective of this study was to evaluate the convenience of the tractor seatbelt. We selected four healthy men as subjects. We measured their body pressure and examined the comfort of the seatbelt, while driving 50m on three different types of agricultural road with two types of seatbelts: automatic and manual. As results, when they used manual seatbelt, subjective uncomfortable rate was much higher than the automatic seatbelt on all types of road. Especially, body pressure was undistributed while using manual seatbelt on rough road.
\end{abstract}

Keywords: Seatbelt, Human-body pressure distribution, Comfort evaluation, Subjective assessment

\section{Introduction}

2005년도 통계청 조사에 의하면 농촌에 종사하는 사람의 평균 연령은 60 세 이상이 $58.3 \%$ 이며 전체 인구에 비해 3 배 이상 고령화가 진행된 것으로 나타났다. 이에 따라 현재 농촌에서는 노령자와 부녀자의 농기계 사용이 농작업에서 증가하는 추세에 있다. 2007년 농기계에 의한 사망사고 건 수는 167 건에 달하는 것으로 집계된 가운데 $78.6 \%$ 가 경운 기와 트랙터에 의한 사고였던 것으로 보고되었다. 이러한 트 랙터 안전사고로부터 농작업자를 보호하기 위한 안전장치의 하나로 좌석벨트가 있으며, 특히 트랙터 전도 및 전락사고 시에 좌석벨트는 사망사고 예방에 큰 역할을 할 수 있다. 그 러나 트랙터 운전 시의 좌석벨트 장착률은 $44 \%$ 에 지나지 않으며 좌석벨트가 트랙터에 장착되어 있는데도 좌석벨트 미장착자의 $94 \%$ 가 이를 이용하지 않고 있는 것으로 나타 났다.

이와 같이 트랙터 좌석벨트의 장착율이 낮은 이유로는 사 용자의 안전의식의 결여와 더불어 벨트 사용 시의 불편함을
들 수 있다. 일반적으로 좌석벨트의 불편한 정도는 벨트착용 시의 안락감으로 평가를 할 수 있는데 객관적인 평가방법으 로 박막형 압력센서를 사용하여 체압분포를 측정하고, 주관 적 평가와 비교하여 전체적인 좌석벨트의 안락감을 평가하 기도 한다(Lee et al., 2000). Oudenhuijzen(2003)는 두 대의 다른 차량(sedan, MPV)의 시트에서 발생하는 체압분 포의 정도가 두 시트의 안락함의 정도를 평가하는 중요한 요인이 된다는 연구결과를 발표하였다. 한편, $\mathrm{Bak}$ (2007)은 시트밑판과 발판의 높이가 변함에 따른 체압분포의 차이가 불편함에 주는 영향을 분석하기 위해 주관적 평가로 크기예 측법을 이용하였고, 객관적 평가로는 시트의 체압분포를 측 정하여 불편함을 수치화하고 이러한 주관적 수치와 객관적 수치의 상관도를 분석하였다. $\mathrm{Na}$ (2003)는 연속적인 체압의 변화를 동적체압분포(Dynamic body pressure distribution) 라고 정의하였으며, 이 동적체압분포를 이용하여, 운전자세 의 변화를 분석하고 운전환경을 평가하였다. Lee(2007)는 자동차시트의 체압측정을 통한 안락감 평가를 위해 다양한 피험자의 주관적 평가와 함께 객관적 평가법으로 체압측정 을 하고 상관관계를 분석하였다. 
이 논문에서는 고령자와 부녀자를 포함하는 모든 농업인 이 농용트랙터를 안전하고 편이하게 이용할 수 있도록 하기 위하여 좌석벨트의 안락감을 평가하여 농업인의 좌석벨트 장착률을 높일 수 있는 좌석벨트 방식을 제안하는 것을 목적 으로 한다.

\section{Research Method}

\subsection{Subject}

이 연구의 목적 달성을 위하여 운전 경력이 3년 이상인 25 40대 남자 4명을 피실험자로 선정하였다. 피실험자는 체압분포 측정에 영향을 줄 수 있는 벨트나 지갑 등을 제거 하고 바지나 가벼운 셔츠를 착용하도록 하였다. 4 명의 피실 험자는 각자 5 회 반복 실험을 하여, 불규칙하게 나오는 극대, 극소값 데이터 1 개를 제거하였다. 개인내 변동과 개인간의 변동을 제거하기 위하여 피실험자가 각각 2종류의 벨트에 대하여 3 가지 주행시험 환경에서 5 회 반복하여 총 120 회의 실험을 수행하였다.

피실험자에게 주행거리가 각각 $50 \mathrm{~m}$ 인 인공악로와 비포장 도로, 포장도로의 3 가지 주행환경에서 주행을 하도록 하고 수동식과 자동식의 2 종류의 벨트에 대한 평가를 실시하였다. 객관적 평가방법으로 체압분포 측정시스템을 이용하여 불편 함을 수치화하였고, 주관적 평가로는 좌석벨트압력, 좌석벨 트 맞춤 경로, 신체부위(엉덩이, 장딴지, 종아리, 발목, 등, 목) 의 불편도를 5 점 척도법으로 측정하였다. 또한 데이터 검 정을 하기 위해 피험자의 주관적 평가와 체압측정값에 대해 통계패키지를 이용하여 분산분석과 상관분석을 실시하였다.

Table 1. Charactoristic data of subjects

\begin{tabular}{c|r|r|r|r}
\hline 항몽계치 & 평균 & 표준편차 & 최대값 & 최소값 \\
\hline 나이(세) & 29.25 & 5.19 & 26 & 37 \\
\hline 앉은키 $(\mathrm{cm})$ & 167.75 & 6.50 & 162 & 177 \\
\hline 몸무게 $(\mathrm{kg})$ & 73.75 & 10.59 & 60 & 85 \\
\hline 허리둘레 $(\mathrm{cm})$ & 31.75 & 2.06 & 29 & 34 \\
\hline 좌석벨트 길이 $(\mathrm{cm})$ & 77.75 & 4.65 & 72 & 82 \\
\hline 앉은 무릎높이 $(\mathrm{cm})$ & 51.55 & 2.22 & 45 & 60 \\
\hline
\end{tabular}

\subsection{Experiment equipment}

\subsubsection{Measurement system of body pressure distribution}

평가에 사용된 체압분포 측정시스템은 독일 노벨사의
Pliance X(256sensors $(32 \times 8), 1.83 \mathrm{~cm}^{2} / 1$ sensor)인 정 압센서로서 절대치의 압력값 센서의 Hysteresis가 $3 \%$ 이 내, 압력 측정범위는 $(2 \sim 60 \mathrm{kPa})$ 이다(Figure 1).
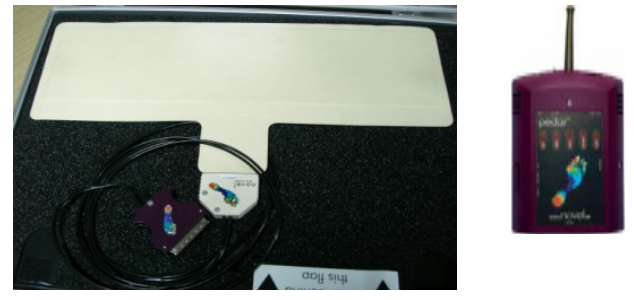

Figure 1. Measurement instrument of body pressure distribution

\subsubsection{Seatbelt winder of formal type}

좌석벨트는 나일론이나 포리에스테르 등의 합성섬유로 만 들어진 안전띠 (Webbing) 와 벨트 자동수납 및 벨트 길이 · 인장력 조정 등을 하는 권취기(Retractor) 그리고 안전띠의 결합 및 해체 기능을 가진 버클(Buckle), 안전띠의 차체 고 정 지지점인 앵커리지(Anchorage) 등으로 구성되어 있다. 평가에 사용된 좌석벨트는 일반적으로 트렉터에 많이 채용 되어 있는 2점식으로 권취기가 없는 수동식과 자동잠금식 권취기를 선정하였다.

\subsubsection{Agricultural tractor}

평가에 사용된 농용트랙터는 농가에서 많이 보급되어 있 고 일반적으로 사용하는 트렉터를 선정하였으며 사양은 다 음과 같다(Table 2와 Figure 2).

Table 2. Specification of agricultural tractor

\begin{tabular}{c|c}
\hline & 농용트랙터 사양 \\
\hline 공시품 명칭 & $\begin{array}{c}\text { 농용트랙터 } \\
\text { (형식명: TA5240) }\end{array}$ \\
\hline 기체형식 & 4륜구동형 디젤52마력 \\
\hline 타이어조건 & $\begin{array}{c}\text { 전륜 } 8.3 \sim 206 \mathrm{PLY}, \\
\text { 후륜 } 12.4 ~ 32 ~ 6 \mathrm{PLY}\end{array}$ \\
\hline 트랙터의 차륜거리 & 전륜 $1220 \mathrm{~mm}$ \\
\hline 트랙터의 축간거리 $1220 \mathrm{~mm}$
\end{tabular}




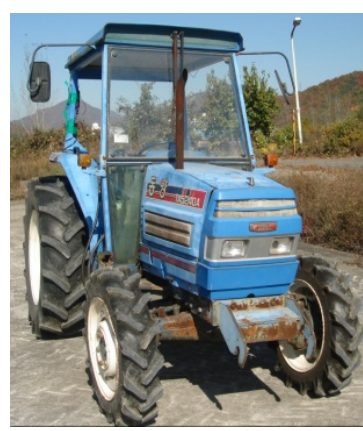

Figure 2. Agricultural tractor used in the experiment

\subsection{Experiment plan}

좌석벨트의 안락감 평가를 위한 실험은 3종류의 각기 다 른 주행환경(인공악로, 비포장도로, 포장도로)에서 $50 \mathrm{~m}$ 길 이의 주행 코스를 5회 반복해서 운행하도록 하면서 수동식 과 자동식벨트에 대한 체압분포를 측정하였다. 인공악로는 불규칙적인 굴곡으로 형성되어 있고, 포장도로는 시멘트로 이루어졌으며, 비포장도로는 자갈과 흙으로 구성되어 있다 (Figure 3). 주행속도는 인공악로에서 $7.5 \mathrm{~km} / \mathrm{h}$ 이고, 비포 장도로와 포장도로에서 $20 \mathrm{~km} / \mathrm{h}$ 로 하였다.

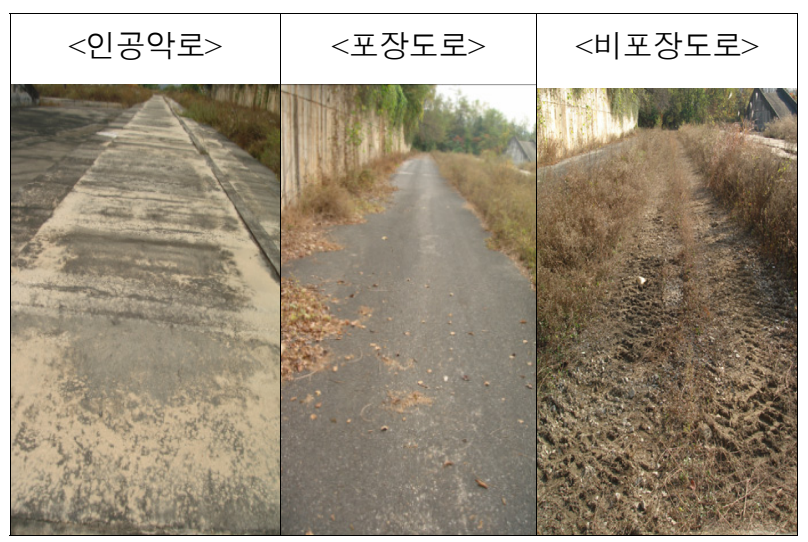

Figure 3. Three types road of used in the experiment

\subsection{Experiment procedure}

Table 3 는 측정항목별 실험절차를 표시한 것으로 전반적 인 실험절차는 다음과 같이 6단계로 구분하였다.

1단계: 좌석시트를 각 운전자가 가장 편안한 상태로 조절 한다(시트의 전후, 높이, 각도 및 운전대).

2단계: 좌석벨트(자동식, 수동식)를 착용한다. 자동식벨트를 먼저 착용하여, 그 길이만큼 수동식벨트를 조절한다.
3단계: 체압측정을 위한 체압센서 매트를 벨트안쪽에 착용 한다(Figure 4).

4단계: 시험장소에서 $50 \mathrm{~m}$ 을 운행한다.

5단계: 운행 완료 후 피험자의 주관적 벨트압에 대한 신체 불편도를 조사하기 위해 설문조사를 실시한다.

6단계: 벨트에서 체압센서 매트를 제거하고, 시트를 설계표 준상태로 원위치시킨다.

Table 3. Measurement itemized experiment procedure

\begin{tabular}{c|c|c|c|c|c}
\hline & \multicolumn{4}{|c}{ 실험구간 $(50 \mathrm{~m})$} \\
\hline 측정항목 & 안정 & 출발 & 주행 & 정지 & \\
\hline 체압분포 & \multicolumn{5}{|c}{$\triangle \triangle \triangle$ 연속측정 $\triangle \triangle \triangle$} \\
\hline 주관적 평가 & \multicolumn{5}{|c|}{ ム } \\
\hline
\end{tabular}

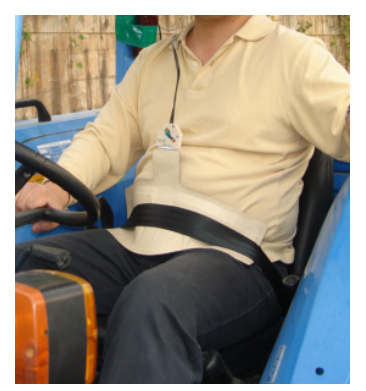

Figure 4. Measuring the body pressure while wearing manual seatbelt

\subsection{Measurement consideration}

체압분포는 일반적으로 피실험자의 운전자세와 호흡, 배 둘레 등에 민감하게 영향을 받는 것으로 알려져 있다. 이러 한 특성들을 고려하여 센서의 부착위치와 수동식과 자동식 벨트의 길이 등을 가능한 동일하게 조정하였으며, 미세한 신체 움직임에 대한 영향을 최소화하기 위하여 피실험자가 안정을 취할 수 있도록 하여 호흡이 일정한 상태를 유지하게 한 후에 측정을 실시하였다.

\section{Experiment Result and Analysis}

\subsection{Subjective evaluation}

주관적 평가방법으로서 좌석벨트의 압력과 6 개 신체부위 (엉덩이, 장딴지, 종아리, 발목, 등, 목)에 대한 피험자가 주 관적으로 느끼는 불편도를 5점 척도법(1: 매우 편안함, 2 : 
편안함, 3: 보통, 4: 불편함, 5: 매우 불편함)으로 측정하였다.

Table 4는 수동식과 자동식벨트의 착용에 따른 신체부위 에 가해지는 압력에 대한 주관적 불편도를 비율로 나타낸 것 이다. 수동식 좌석벨트와 자동식 좌석벨트 모두 인공악로와 비포장도로에서 포장도로에 비해 불편하게 느끼는 것으로 나타났다.

Table 4. Comfort rate of manual and automatic seatbelt

\begin{tabular}{c|c|c|c|c|c|c}
\hline \multirow{2}{*}{$\begin{array}{c}\text { 주관적 } \\
\text { 불편도 }\end{array}$} & \multicolumn{2}{|c|}{ 인공악로 } & \multicolumn{2}{c|}{ 포장 } & \multicolumn{2}{c}{ 비포장 } \\
\cline { 2 - 7 } & 수동식 & 자동식 & 수동식 & 자동식 & 수동식 & 자동식 \\
\hline 매우 편안함 & & & & & & \\
\hline 편안함 & & & $25 \%$ & $0 \%$ & & \\
\hline 보통 & $25 \%$ & $0 \%$ & $75 \%$ & $100 \%$ & $25 \%$ & $0 \%$ \\
\hline 불편함 & $75 \%$ & $100 \%$ & & & $75 \%$ & $100 \%$ \\
\hline 매우 불편함 & & & & & & \\
\hline
\end{tabular}

Figure 5는 수동식과 자동식의 좌석벨트의 신체부위별 전 체 주관적 불편도를 점수화한 것을 비교하여 나타낸 것이다. 개관해 보면 자동식보다 수동식이 모든 주행환경에서 전체 적으로 불편도가 높은 것으로 나타났다. 특히 수동식 좌석벨 트는 농작업 환경과 유사한 인공악로에서 불편도가 매우 높 으며 자동식 좌석벨트와 비교하여 유의하게 높은 것으로 나 타났다.

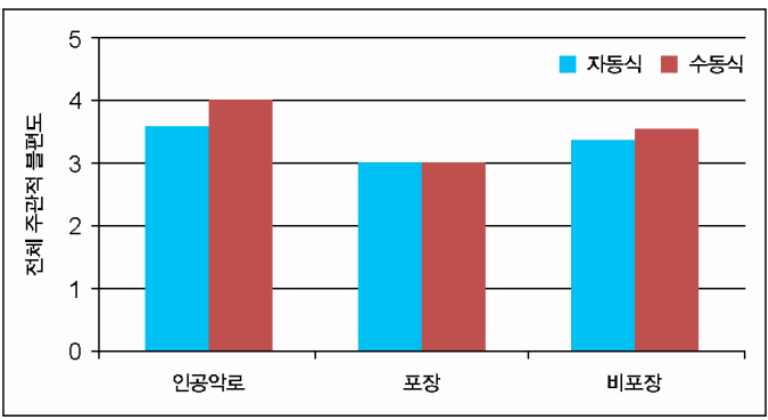

Figure 5. Comfort rate of total body parts according to the manual and automatic seatbelt

Figure 6는 신체부위별 주관적 불편도를 수동식과 주관식 을 비교하여 나타낸 것으로 개관해 보면 수동식과 자동식 모두 장딴지와 발목이 다른 신체부위보다 불편도가 높게 나 왔다. 특히 말목부위의 불편도가 가장 높게 나타났다. 수동 식과 비교하여 자동식의 불편도가 장딴지, 종아리, 발복부위 에서 유의하게 높은 것으로 나타났다.

\subsection{Variance analysis of subjective evaluation}

주행환경(인공악로, 포장도로, 비포장도로)에 따른 벨트압 력에 대한 불편도의 평균값에 대한 분산분석 결과에 의하면 주행환경에 따라 자동식과 수동식간에 피험자간의 불편도에 유의한 차이가 있는 것으로 나타났다 $(\alpha=0.05)$. 또한 좌석 벨트의 종류에 따른 분산분석표 결과에서도 수동식과 자동 식의 좌석벨트의 종류에 따라 좌석벨트의 압력에 대한 불편 도에도 유의한 차이가 있는 것으로 나타났다.

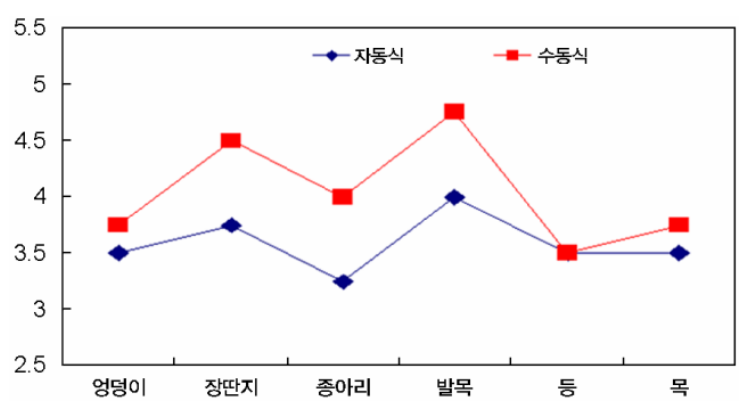

Figure 6. Comfort rate of body parts according to the manual and automatic seatbelt

Table 6. Variance analysis of subjective evaluation of seatbelt pressure according to agricultural road and seatbelts

\begin{tabular}{c|c|c|c|c|c|c}
\hline $\begin{array}{c}\text { 변동의 } \\
\text { 요인 }\end{array}$ & 제곱합 & 자유도 & 제곱평균 & $\mathrm{F}$ 비 & $P$-값 & $\mathrm{F}$ 기각치 \\
\hline 주행환경 & 4.75 & 2 & 2.38 & 17.1 & $6.89 \mathrm{E}-05$ & 3.55 \\
\hline 벨트압력 & 0.67 & 1 & 0.67 & 4.8 & 0.04 & 4.41 \\
\hline 교호작용 & 0.08 & 2 & 0.04 & 0.3 & 0.74 & 3.55 \\
\hline 잔차 & 2.50 & 18 & 0.14 & & & \\
\hline 계 & 8 & 23 & & & & \\
\hline
\end{tabular}

자동식과 수동식 좌석벨트 착용 시 주행환경에 따른 신체 부위별 주관적 불편도에 대한 분산분석 결과에서 $\mathrm{F}$ 검정 통 계값은 11.62 와 22.69 로서 유의수준 0.05 인 경위의 $\mathrm{F}$ 기 각치 3.17 보다 모두 큰 것으로 나타나 주행환경에 따라 신 체부위별 주관적 불편도에 유의한 차이가 있는 것으로 나타 났다(Table 7, Table 8).

\subsection{Result of body-pressure distribution}

체압분포의 결과를 분석하기 위하여 $\mathrm{MPP}$ (Maximum Pressure Picture) 방식을 사용하였다. Figure 7은 좌석벨 트의 센서를 그림으로 나타낸 것으로, $32 \times 8$ 의 256 개의 센 서들로 구성되어 있다. 각 센서들에서 나온 값 $(\mathrm{Sx}, \mathrm{y})$ 에서 
Table 7. Variance analysis of subjective evaluation of agricultural road and body parts, while wearing automatic seatbelt

\begin{tabular}{c|c|c|c|c|c|c}
\hline $\begin{array}{c}\text { 변동의 } \\
\text { 요인 }\end{array}$ & 제곱합 & 자유도 & 제곱평균 & $\mathrm{F}$ 비 & $P$-값 & $\mathrm{F}$ 기각치 \\
\hline 작업로 & 4.19 & 2 & 2.10 & 11.62 & $6.37 \mathrm{E}-05$ & 3.17 \\
\hline 신체별 & 2.24 & 5 & 0.45 & 2.48 & 0.04 & 2.39 \\
\hline 교호작용 & 1.47 & 10 & 0.15 & 0.82 & 0.62 & 2.01 \\
\hline 잔차 & 9.75 & 54 & 0.18 & & & \\
\hline 계 & 17.65 & 71 & & & & \\
\hline
\end{tabular}

Table 8. Variance analysis of subjective evaluation of agricultural road and body parts, while wearing manual seatbelt

\begin{tabular}{c|c|c|c|c|c|c}
\hline $\begin{array}{c}\text { 변동의 } \\
\text { 요인 }\end{array}$ & 제곱합 & 자유도 & 제곱평균 & $\mathrm{F}$ 비 & $P$-값 & $\mathrm{F}$ 기각치 \\
\hline 작업로 & 13.03 & 2 & 6.51 & 22.69 & $7.03 \mathrm{E}-08$ & 3.17 \\
\hline 신체별 & 4.61 & 5 & 0.92 & 3.21 & 0.01 & 2.39 \\
\hline 교호작용 & 2.81 & 10 & 0.28 & 0.98 & 0.47 & 2.01 \\
\hline 잔차 & 15.50 & 54 & 0.29 & & & \\
\hline 계 & 35.94 & 71 & & & & \\
\hline
\end{tabular}

시간대별 $(\mathrm{sec})$ 로 나온 값 $\left(\mathrm{S}^{\mathrm{t}} \mathrm{x}, \mathrm{y}\right)$ 중 최대값 $\left(\operatorname{Max}\left(\mathrm{S}^{\mathrm{t}} \mathrm{x}, \mathrm{y}\right)\right)$ 을 이용하여 체압분포의 평균값과 최대값을 구하였다(식 1 , 식 2).

Mean $\left\{\operatorname{Max}\left(\mathrm{S}^{\mathrm{t}} \mathrm{x}, \mathrm{y}\right)\right\}$

$\operatorname{Max}\left\{\operatorname{Max}\left(\mathrm{S}^{\mathrm{t}} \mathrm{x}, \mathrm{y}\right)\right\}$

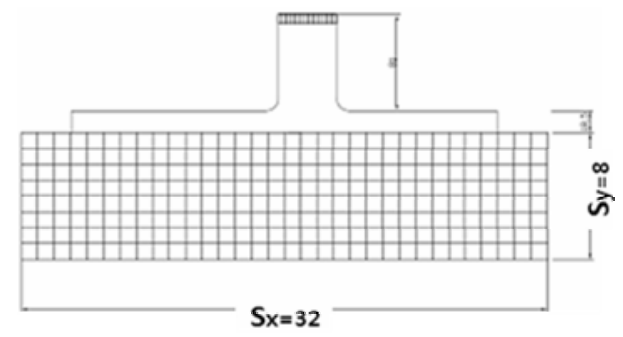

Figure 7. Seatbelt sensor

Figure 8과 Figure 9는 주행환경에 따른 수동식과 자동 식 좌석벨트의 체압분포 그래프를 나타낸 것으로 개관해 보 면 그래프에서 나타내는 바와 같이 수동식벨트의 체압값이 전반적으로 많이 높게 편중되는 것으로 나타났다. 주행환경 의 굴곡이 심할수록 즉 인공악로, 비포장도로, 포장도로 순 으로 체압값이 많이 편중되어 높게 나타나는 것으로 나타 났다.

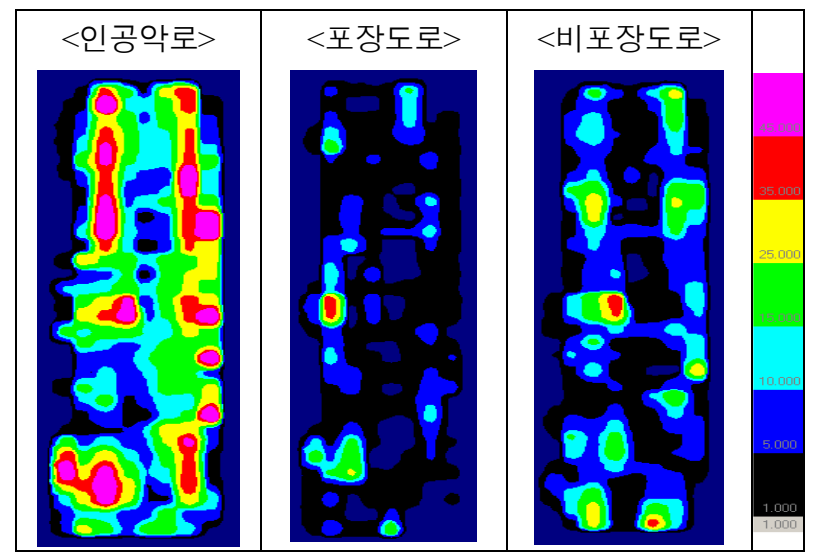

Figure 8. Average value of body-pressure distribution of manual seatbelt according to the agricultural road

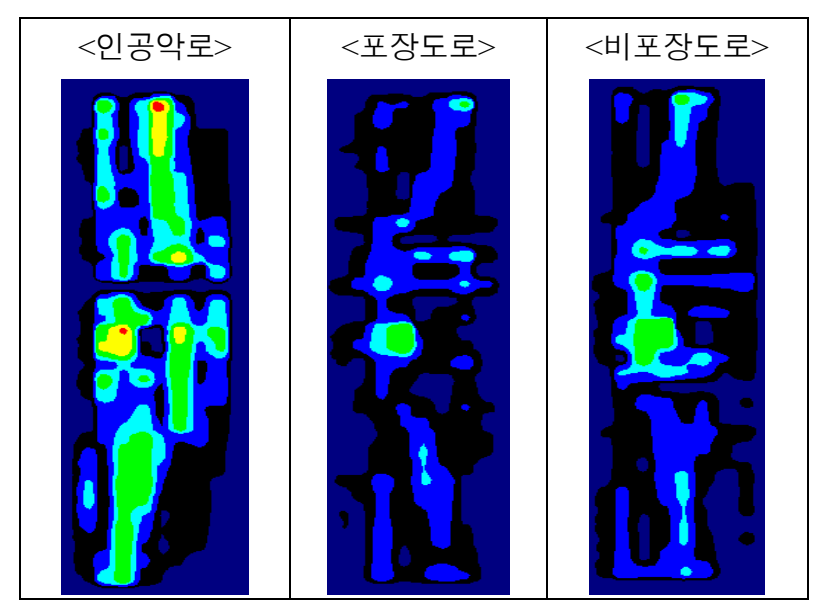

Figure 9. Average value of body-pressure distribution of automatic seatbelt according to the agricultural road

수동식 좌석벨트를 착용하고 주행하는 경우에 자동식 좌 석벨트를 착용하는 것보다 대체적으로 높게 나왔으며, 수동 식과 자동식벨트를 착용 시에 인공악로, 비포장도로, 포장도 로 순으로 체압이 높게 나왔다. 특히, 수동식벨트를 착용하 고 인공악로에 주행 시에 체압분포가 가장 높게 나왔다. 체 압분포는 가장자리보다는 앞쪽이 높은 압력을 받는 것으로 나타났다.

주행환경에 따른 평균 체압값을 보면 전체적으로 자동식 이 수동식벨트보다 작게 나타났다. 또한, 주행환경별로 보면 인공악로, 비포장, 포장 순으로 체압이 높게 나왔다(Figure 10). 최대 체압값을 보면, 인공악로에서 수동식이 자동식보 다 체압값 차이가 가장 높은 것으로 나타났다(Figure 11). 


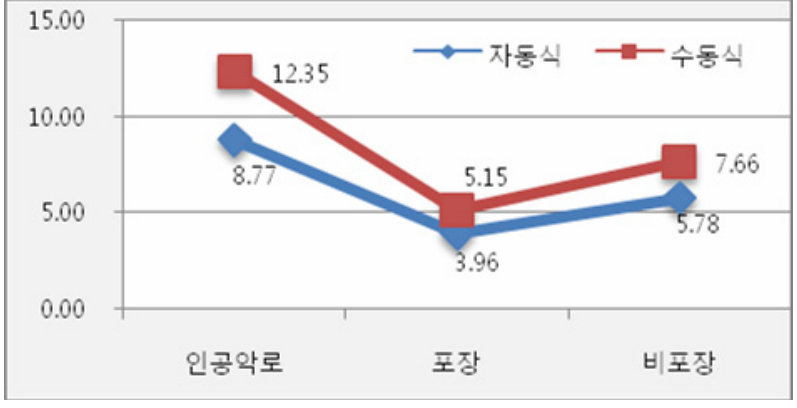

Figure 10. Average body-pressure value $[\mathrm{kPa}]$ according to the agricultural road of wearing automatic and manual seatbelt

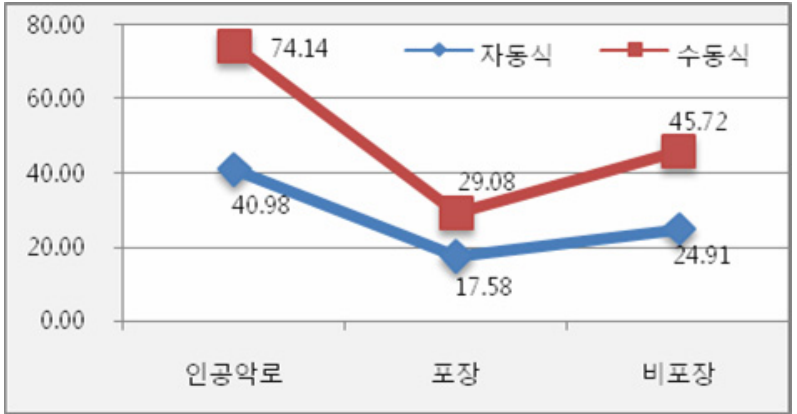

Figure 11. Maximum body-pressure value $[\mathrm{kPa}]$ according to the agricultural road of wearing automatic and manual seatbelt

\subsection{Variance analysis of body-pressure distribution}

주행환경에 따른 분산분석표 결과를 보면, $\mathrm{F}$ 검정 통계값 은 137.88 로서 유의수준 0.05 인 경우의 $\mathrm{F}$ 기각치 3.55보 다 큰 것으로 나타났다. 즉, 주행환경에 따라 자동식과 수동 식 좌석벨트를 착용 시의 피실험자간의 체압평균에 유의한 차이가 있었다(Table 9).

Table 9. Repeatable two-way variance analysis of agricultural road and seatbelts(automatic and manual)

\begin{tabular}{c|r|r|r|r|c|c}
\hline $\begin{array}{c}\text { 변동의 } \\
\text { 요인 }\end{array}$ & 제곱합 & 자유도 & 제곱평균 & $\mathrm{F}$ 비 & $P$-값 & $\mathrm{F}$ 기각치 \\
\hline 작업로 & 147.79 & 2 & 73.89 & 137.88 & $1.22 \mathrm{E}-11$ & 3.55 \\
\hline 벨트별 & 29.48 & 1 & 29.48 & 55.01 & $7.08 \mathrm{E}-07$ & 4.41 \\
\hline 교호작용 & 6.00 & 2 & 3.00 & 5.60 & 0.013 & 3.55 \\
\hline 잔차 & 9.65 & 18 & 0.54 & & & \\
\hline 계 & 192.92 & 23 & & & & \\
\hline
\end{tabular}

좌석벨트에 따른 검정(열효과 검정)의 분산분석표 결과에 서 $\mathrm{F}$ 검정 통계값은 55.01로서 유의수준 0.05 인 경우의 F
기각치 4.41보다 크다. 따라서 좌석벨트(수동식, 자동식)에 따라 각각의 주행환경에서 체압평균에 유의한 차이가 있는 것으로 나타났다.

또한 주행환경과 좌석벨트간의 교호작용 검정을 보면, 분 산분석표의 결과에서 교호작용비는 5.60로서 유의수준 0.05 인 경우의 $\mathrm{F}$ 기각치 3.55 보다 크다. 즉, 주행환경과 좌석벨 트간에 교호작용이 있는 것으로 나타났다.

\subsection{Correlation}

자동식과 수동식 좌석벨트는 각각의 주행환경인 인공악로, 포장, 비포장에서의 체압분포와 주관적 좌석벨트의 압력에 대한 불편도에서 각각 0.79 와 0.77 의 양의 상관관계에 있는 것으로 나타났다.

또한 자동식과 수동식 좌석벨트를 착용하여 인공악로, 포 장, 비포장도로에서 주행시 체압분포와 신체부위의 불편도의 상관관계분석을 결과, 체압분포는 대체로 신체부위 중에서도 장딴지, 종아리, 등, 발목과 상관관계가 높은 것으로 나타났 다(Table 10).

Table 10. Comfort correlation of body-pressure distribution and body parts in automatic and manual seatbelt

\begin{tabular}{c|c|c|c|c|c|c}
\hline 자동식 & 엉덩이 & 장딴지 & 종아리 & 발목 & 등 & 목 \\
\hline 체압값 & .433 & $.598^{*}$ & .500 & $.791^{* *}$ & $.614^{*}$ & .265 \\
\hline$p$ value & .160 & .040 & .098 & .002 & .034 & .405 \\
\hline
\end{tabular}

\begin{tabular}{c|c|c|c|c|c|c}
\hline 수동식 & 엉덩이 & 장딴지 & 종아리 & 발목 & 등 & 목 \\
\hline 체압값 & .290 & $.679^{*}$ & $.850^{* *}$ & $.822^{* *}$ & .336 & .487 \\
\hline$p$ value & .360 & .015 & .000 & .001 & .285 & .108 \\
\hline
\end{tabular}

*상관계수는 0.05 수준에서 유의

**상관계수는 0.01 수준에서 유의

\section{Conclusion}

이 연구에서는 인공악로, 비포장도로, 포장도로의 각기 다 른 주행환경에서 농용트랙터를 운행 시에 발생되는 수동식 과 자동식 좌석벨트의 안락감을 평가하기 위하여 체압을 측 정하고 벨트의 착용시 주관적 불편도를 평가하였다. 주관적 불편도 평가에 의한 자동식 벨트와 수동식벨트를 비교한 결 과, 각각의 주행환경에서 자동식보다 수동식벨트가 전체적으 로 불편도가 높은 것으로 나타났으며 명확한 차이를 볼 수 있었다. 또한 자동식 벨트와 수동식벨트의 두 방법에 대한 
분산분석과 상관관계를 분석한 결과, 주행환경 별로 체압분 포에 유의한 차이가 있는 것으로 나타나 그 유효성을 평가 할 수 있었다. 결과로서 인공악로에서 체압분포가 편중되어 전체적으로 안락감이 좋지 않은 결과로 나타났다. 또한 주관 적인 불편도와 객관적인 체압분포에서도 자동식 벨트가 수 동식 벨트보다 안락감이 높은 것으로 나타났다.

향후, 소형, 중형, 대형의 트랙터의 크기별로 좌석벨트의 평가가 수행될 필요성이 있으며 농작업 시의 후방 주시 시의 안락감에 대한 심층적 연구도 필요하다.

\section{References}

Na, S. H., Im, S. H. and Jeong, M. G., Quantitative Evaluation of Driver's Postural Change and Lumbar Support Using Dynamic Body Pressure Distribution, Ergonomics Society of Korea, 22(3), 57-73, 2003.

Bak, D. G., An, S. U. and Yu, W. S., Study on Relationship between Discomfort and Body Pressure Distribution on the Seat under Height of Footrest and Angle of Seatpan, The Korea Society of Automotive Engineers, 15(6), 38-43, 2007.

Bak, S. J., Yi, N. S. and Yi, S. Y., An investigation of the relationship between subjective comfort evaluation and body pressure distribution of vehicle seats, Ergonomics Society of Korea, 12(1), 3-15, 1993.

Lee, J. W., Bak, S. J. and Gang, Y. S., A Study on the Evaluation of Shoulder Strap Comfort using the Body Pressure Distribution, Ergonomics Society of Korea Symposium, 104-107, 2000.

Lee, H. C., Bak, H. M., Nn, H. H., Kim, C. S., Jo, H. I. and Jeon, O. W., A Study on the Comfort Evaluation Method for Automotive Seat, The Korea Society of Automotive Engineers Spring Conference, 1412 $-1416,2007$.
Oudenhuijzen, K. Tan and F. Morsch, The relationship between seat pressure and comfort, SAE no 2003-01-2213, 2003.

\section{Author listings}

Kwan Woo Kim: kwkim@efact.or.kr

Highest degree: $\mathrm{PhD}$, Department of Industrial Engineering, Tokyo Metropolitan Institute of Technology

Position title: Researcher, Foundation of Agri. Tech. Commercialization and Transfer

Areas of interest: HCI, Agricultural Work Safety

Hyuk Joo Kim: hjkim@rda.or.kr

Highest degree: $\mathrm{PhD}$, Department of Bio-system, Kyungbuk University Position title: Researcher, 2National Institute of Agricultural Engineering Areas of interest: Agricultural Machine Safety

Keun Sang Park: ergpark@konkuk.ac.kr

Highest degree: Dr. of Eng., Department of Industrial \& Management Engineering, Nihon University

Position title: Professor, Department of Industrial Engineering, Konkuk University

Areas of interest: Agricultural Ergonomics, Work Stress, Products Design

Date Received : 2011-07-14

Date Revised :2011-07-29

Date Accepted : 2011-07-29 